\title{
Analisis Permasalahan dalam Proses Pembelajaran Daring Siswa pada Masa Pandemi Covid-19 di SDN 066652 Medan
}

\author{
Winny Sunfriska br Limbong1), Taruli Marito Silalahi' ${ }^{2)}$, Devi Bungaria br Simbolon ${ }^{3)}$ \\ 1), 2), 3) Universitas Sari Mutiara, Indonesia \\ ${ }^{1)}$ friskawinny@gmail.com, ${ }^{2}$ taruli766hi@gmail.com, ${ }^{3}$ )devibunga188@gmail.com
}

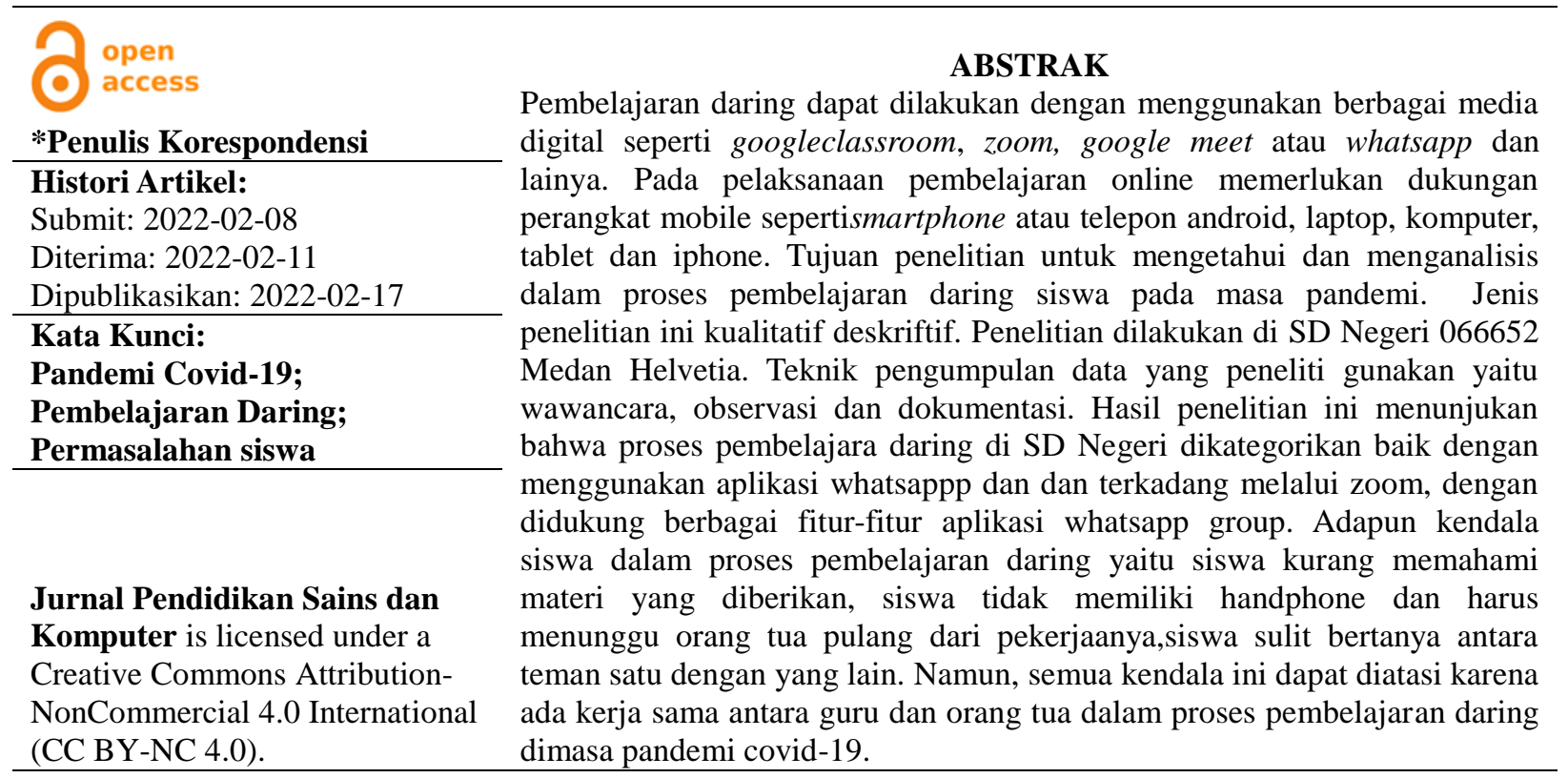

\section{PENDAHULUAN}

Di negara kita Indonesia bahkan seluruh dunia dihebohkan dengan corona virus. Corona virus ini menyebar di Indonesia pada awal tahun 2020 dan pertama kali muncul di kota Wuhan, China pada akhir desember tahun 2019. Hal ini menyebabkan beberapa negara bahkan mungkin di semua negara menerapkan kebijakan untuk memberlakukan lockdown dalam rangka mencegah penyebaran virus corona tersebut.di Indonesia sendiri memberlakukan sistem PSBB, PSBB itu sendiri adalah singkatan dari "Pembatasan Sosial Berskala Besar". Hal ini diberlakukan agar semua masyarakat Indonesia dapat mengurangi keterlibatan antara satu dengan yang lain dan juga bisa menjaga jarak (Sari.R.P dkk 2021:10).

Mengingat bahwa pendidikan merupakan sektor utama dalam pembangunan bangsa Indonesia sehingga pelaksanaan proses pendidikan pada masa pandemi tidak boleh sampai terhenti dan pendidikan diindonesia harus terlaksana dengan metode pembelajaran daring ini merupakan salah satu alternatif agar proses pendidikan tetap berjalan dimasa pandemi dengan bantuan berbagai media komunikasi (Juliya, M. 2021: 282).

Pembelajaran daring dilakukan sesuai dengan kemampuan sekolah masing-masing. Belajar online dapat menggunakan berbagai media digital seperti google classroom, rumah belajar, Zoom, google meet atau whatsapp dan lainya. Pada pelaksanaan pembelajaran online memerlukan dukungan perangkat 


\section{Jurnal Pendidikan Sains dan Komputer}

mobile seperti smartphone atau telepon android, laptop, komputer, tablet dan iphone yang dapat dipergunakan untuk mengakses informasi kapanpun dan dimanapun (Purnamasari 2020:33).

Kondisi ini membuat guru mengubah metode belajar mengajarnya. Penggunaan metode yang tepat maupun perilaku dan sikap guru dalam mengelola proses belajar mengajar sangat dibutuhkan dalam pembelajaran selama program belajar dari rumah. Penerapan pembelajaran online telah dilaksanakan dihampir seluruh sekolah di Indonesia. Namun melihat dari berbagai hasil penelitian bahwa proses pembelajaran daring di indonesia masih belum sepenuhnya terlaksana secara baik, karena banyak permasalahan ataupun kendala yang dialami seperti dalam pengoperasian media komunikasi, baik dari tenaga pendidik maupun siswa, seperti jaringan yang kurang stabil, tidak semua siswa memiliki akses untuk melakukan pembelajaran online dan lain sebagainya (Anwar K.dkk 2020:35).

Purnamasari, dkk (2020:3) menyatakan bahwa masih ada siswa yang mendapatkan nilai tidak memuaskan dan masih banyak siswa yang tidak mengerjakan soal evaluasi. Hal ini di karenakan siswa memiliki hambatan pada jaringan internet yang tidak lancar, tidak memliki kouta internet, kesulitan memahami pelajaran, dan tidak ada sarana handphone maupun komputer. Penelitian lain juga dilakukan oleh Prawanti, Lia Titi dan Woro Sumarni (2020:286) tentang Kendala Pembelajaran Daring Selama Pandemic Covid-19, ditemukan bahwa kurangnya pengetahuan tentang teknologi informasi oleh peserta didik maupun orangtua peserta didik, kemudian pembelajaran menjadi membosankan dan penilaian pembelajaran yang seharusnya bisa dilakukan secara langsung menjadi tidak bisa dilakukan.

Attri (2012) menyatakan bahwa terdapat beberapa masalah atau kendala yang dihadapi siswa pada saat pelaksanaan pembelajaran online, seperti biaya, motivasi belajar, layanan, umpan balik, kurangnya pengalaman kebiasaan.Sebagaimana yang dijelaskan Erni, et al (2020) dalam Amalia menyatakan bahwa jaringan juga menghambat pembelajaran online.

Berdasarkan observasi dan wawancara terdahulu yang peneliti lakukan tepatnya pada tanggal 15 Maret 2021 di SD Negeri 066652 Medan. Peneliti melihat langsung proses belajar mengajar yang dilakukan Ibu guru kelas 4 bernama Ida Damayanti dengan menggunakan aplikasi whatsapp. Ia menyatakan bahwa dalam pembelajaran daring ini guru menggunakan aplikasi whatsapp dan kadangkadang Zoom. Pada proses pembelajaran daring ini menurut ibu Ida Damayanti belum maksimal dikarenakan ada bebrapa siswa yang memiliki hambatan seperti tidak memiliki handphone dan keaktifan siswa kurang dari pada tatap muka. Pada tanggal 16 maret 2021 peneliti melakukan wawancara kepada 3 orang siswa.Dari hasil wawancara dengan siswa SDN 066652 Medan, peneliti menemukan permasalahan siswa seperti, siswa tidak hadir didalam pembelajaran secara daring, tidak ada fasilitas dari orangtua yang mendukung, kouta internet yang belum terpenuhi, jaringan yang kurang maksimal, siswa kurang memahami materi pembelajaran dan kurangnya partisipasi dari orangtua. Purnama (2020) menyimpulkan peran orang tua dalam mengatasi permasalahan siswa dapat teratasi dengan baik dimana orang tua dapat memantau perkembangan belajar siswa dan mengawasi anaknya agar dapat mengikuti pelajaran daring dengan baik.

Permasalahan dalam pembelajaran daring bagi siswa menjadi hal yang penting untuk dianalisis dan dikaji. Di antara permasalahan yang dihadapi siswa dalam mengikuti pembelajaran daring yaitu ketidak hadiran siswa dalam pembelajaran daring, siswa kurang memahami materi pembelajaran, kouta internet tidak memadai, jaringan tidak stabil dan tidak ada fasilitas yang mendukung dari orangtua dalam pembelajaran daring dan kurangnya partisipasi orangtua. Oleh karena itu maka perlu dilakukan penelitian 


\section{Jurnal Pendidikan Sains dan Komputer}

mengenai "Analisis Permasalahan dalam Proses Pembelajaran Daring Siswa Pada Masa Pandemi Covid19 di SDN 066652 Medan”.

\section{STUDI LITERATUR}

Pembelajaran daring dilakukan sesuai dengan kemampuan sekolah masing-masing. Belajar online dapat menggunakan berbagai media digital seperti google classroom, rumah belajar, Zoom, google meet atau whatsapp dan lainya. Pada pelaksanaan pembelajaran online memerlukan dukungan perangkat mobile seperti smartphone atau telepon android, laptop, komputer, tablet dan iphone yang dapat dipergunakan untuk mengakses informasi kapanpun dan dimanapun (Purnamasari 2020:33).

Basar.A.M (2021:208) tentang problematika pembelajaran jarak jauh pada masa pandemi covid19 dengan hasil masih banyak peserta didik yang kurang aktif dalam mengikuti pembelajaran jarak jauh, di sebabkan jaringan internet yang kurang stabil maupun dari segi penyediaan kouta internet yang terbatas. Hal ini membuktikan bahwa pembelajaran jarak jauh di masa pandemi covid-19 menimbulkan berbagai tanggapan dan perubahan pada sistem belajar yang dapat mempengaruhi proses pembelajaran serta tingkat perkembangan peserta didik dalam merespon materi yang di sampaikan.

Sejalan dengan penelitian Juliya.M.dkk(2021:28)tentang analisis problematika pembelajaran daring dan pengaruhnya terhadap motivasi belajar siswa dengan hasil masih terbatasnya penguasaan teknologi, kesulitan mengakses jaringan internet,ketiadaan fasilitas penunjang belajar, dan kondisi lingkungan yang kurang kondusif.Hal ini mempengaruhi pada motivasi belajar siswa diantaranya peningkatan kompetensi guru, penggunaan metode belajar yang efektif, pemberian bantuan kouta internet dari kemendikbud, dan berkolaborasi antara guru dan orangtua siswa.Prawanti.L.T R. \& Sumarni.W. (2020:286) tentang kendala pembelajaran daring selama pandemi dengan hasil kurangnya pengetahuan tentang teknologi informasi oleh peserta didik maupun orang tua peserta didik, pembelajaran menjadi membosankan dan penilaian pembelajaran yang harusnya bisa dilakukan secara langsung menjadi tidak bisa dilakukan. Dalam hal ini Pembelajaran menjadi kurang efektif karena adanya hambatan-hambatan tersebut.

Penelitian Amalia.U.R. dkk (2020:53) tentang analisis kendala peserta didik dalam pembelajaran online biologi di SMP Negeri Bantul dengan temuan kendala mulai dari kouta internet yang kurang memadai, jaringan yang tidak stabil, kurangnya pemahaman siswa terhadap materi yang telah di sampaikan.hal ini di menunjukan bahwa kendala yang paling banyak dirasakan oleh siswa adalah kurang mampu memahami materi yang telah di sampaikan. Penelitian yang dilakukan Purnamasari.D. \& Nugraheni.N (2020:31) tentang analisis permasalahan siswa pada proses pembelajaran daring kelas 2, 3 dan 4 di SDN Mangkang Kulon 01" dengan hasil penelitian menunjukan masih ada siswa yang mendapatkan nilai tidak memuaskan dan masih banyak siswa yang tidak mengerjakan soal evaluasi. Permasalahan yang dihadapi siswa yaitu jaringan internet yang tidak lancar, tidak memiliki kuota internet, kesulitan memahami pelajaran dan tidak ada sarana Hp atau komputer. Hal ini dengan adanya peran orang tua maka siswa akan terbantu dalam memahami pelajaran, kemudian juga orang dapat memantau perkembangan belajar siswa dan mengawasi anaknya agar dapat mengikuti pelajaran daring dengan baik. 


\section{Jurnal Pendidikan Sains dan Komputer}

\section{METODE}

Jenis Penelitian ini adalah penelitian kualitatif deskriftif pendekatan studi kasus. Menurut Denzin dan Lincon menyatakan bahwa penelitian kualitatif yang menggunakan latar belakang alamiah, dengan maksud menafsirkan fenomena yang terjadi dan dilakukan dengan jalan melibatkan berbagai metode yang ada dalam penelitian kualitatif sedangkan menurut Angginto dan Setiawan (2018:68) menyatakan bahwa dalam penulisanya data dan fakta yang dihimpun berbentuk kata atau gambar dari pada angka. Dalam penulisan laporan berisi kutipan-kutipan atau fakta yang berada di lapangan.Karakteristik penelitian kualitatif menggunakan pendekatan studi kasus.Berdasarkan pernyataan para ahli diatas dapat dapat disimpulkan bahwasanya penelitian kualitatif mempelajari tentang tindakan dan kata-kata untuk mendeskripsikan fenomena yang dialami oleh subjek penelitian secara menyeluruh.Jadi peneliti menggunakan pendekatan studi kasusdan menggunakan jenis penelitian kualitatif. Karena penelitian ini menghasilkan data berupa kata-kata tertulis atau lisan dari orang-orang yang diamati.

Teknik pengumpulan data dalam penelitian ini, dilakukannya indentifikasi wacana dari buku-buku, artikel serta journal ataupun informasi lainya yang berkaitan dengan judul penulisan pada penelitian ini.Dalam rangka untuk mendukung penelitian ini, peneliti melakukan wawancara, observasi serta dokumentasi.

\section{a. Wawancara}

Wawancara dibedakan menjadi 3 jenis yakni ; wawancara pembicaraan informal, wawancara menggunakan petunjuk umum, wawancara baku terbuka, wawancara terstruktur dan tak berstruktur Moleong (2006:135) dalam Zunaika.G (2020:34) penelitian ini menggunakan teknik wawancara mendalam, dengan tujuan agar informasi yang didapat benar-benar dapat dibuktikan dan dapat dipercaya, teknik ini dengan cara tanya jawab dan tatap muka antara peneliti dan informan atau orang yang diwawancarai menggunakan problem wawancara. Dalam hal ini peneliti mengajukan beberapa pertanyaan yang terkait dengan judul peneliti.Informan dalam peneliti ialah guru kelas dan siswa SD Negeri 066652 Medan.

\section{b. Observasi}

Obesrvasi atau pengamatan merupakan suatu teknik atau cara yang mengumpulkan data dengan jalan mengadakan pengamatan terhadap kegiatan yang sedang berlangsung. Didalam pengertian psikologi, observasi atau yang bisa disebut dengan pengamatan, meliputi kegiatan pemuatan perhatian terhadap suatu objek dengan menggunakan selutuh alat indera.Observasi dapat dilakukan melalui penglihatan, penciuman, pendengaran, peraba, dan pengecap.Observasi dapat dilakukan dengan tes, kousioner, rekaman gambar, dan rekaman suara Aprilia.dkk (2020:230).

Selaras dengan pendapat Arikunto.dkk (2008:17) dalam Zunaika.G 2020:33 menyatakan bahwa observasi adalah kegiatan pengamatan atau pengambilan data untuk memotret seberapa jauh efek tindakan telah mencapai batasan.Observasi yang dilakukan peneliti guna untuk memperoleh data yang berkaitan dengan analisis permasalahan dalam proses pembelajaran daring siswapada masa pandemi covid 19 di SD Negeri 066652 Medan.

c. Dokumentasi

Teknik dokumentasi merupakan perlengkapan dari penggunaan penggumpulan data melalui 


\section{Jurnal Pendidikan Sains dan Komputer}

wawancara pada jenis penelitian kualitatif Sugiono (2013:30)dalam penelitian (Zunaika.G 2020:35) Dokumentasi digunakan untuk mengumpulkan informasi mengenai permasalahan dalam penelitian sehingga menambah pembuktian terhadap suatu kejadian. Pengambilan data dokumentasi dilakukan saat berlangsungnya kegiatan wawancara dan observasi, bertujuan untuk memberi penguatan pada penelitian. Dalam penelitian ini dokumen yang dibutuhkan yang berhubungan dengan judul penelitian yang dilakukan peneliti yaitu analisis permasalahan dalam proses pembelajaran daring siswa pada masa pandemi covid 19 SD Negeri 066652 Medan. Data yang digunakan dalam penelitian ini dapat berupa foto ketika guru dan siswa melaksanaan pembelajaran daring dan dokumen lainya yang mendukung penelitian.Data ini digunakan sebagai data pelengkap ataupun data pendukung.

\section{HASIL}

Berdasarkan observasi yang dilakukan oleh peneliti terhadap guru disekolah SD Negeri 066652 Medan, peneliti menyimpulkan guru menggunakan RPP pada saat pembelajaran daring.menyiapkan media pada saat pembelajaran praktikum kemudian guru mempersiapkan bahan ajar.Aplikasi yang guru gunakan dalam pembelajaran daring yaitu whatsapp dan zoom dan kesiapan siswa dalam pembelajaran daring dikatakan baik sebanyak 20 orang mengikuti pembelajaran daring selebihnya mengalami kendala. Kesulitan yang ditemui guru dalam pembelajaran daring masih bisa teratasi dengan komunikasiataupun bekerja bersama orangtua.Ketersedian jaringan internet memerlukan kouta yang cukup dan kategorikan baik.Juliya.M.dkk (2021) menyimpulkan analisis problematika pembelajaran daring dan pengaruhnya terhadap motivasi belajar siswa dengan hasil masih terbatasnya penguasaan teknologi, kesulitan mengakses jaringan internet,ketiadaan fasilitas penunjang belajar, dan kondisi lingkungan yang kurang kondusif.Hal ini mempengaruhi pada motivasi belajar siswa diantaranya peningkatan kompetensi guru, penggunaan metode belajar yang efektif, pemberian bantuan kouta internet dari kemendikbud, dan berkolaborasi antara guru dan orangtua siswa.

Berdasarkan observasi yang dilakukan oleh peneliti terhadap siswa. Peneliti menyimpulkan bahwa aplikasi yang digunakan dalam pembelajaran daring adalah whatsapp dan zoom. Biaya kouta internet yang digunakan dari orang tua dan keadaan jaringan pada saat pembelajaran daring bagus.Namun masih ada kendala bagi siswa yang keadaan rumahnya tidak mendukung dengan akses internet.Kesiapan siswa dalam mengikuti pembelajaran baik. Kesulitan yang ditemui siswa dalam proses pembelajaran daring adalah sulit bertanya kepada guru dan kurang memahami materi. Pemahaman materi yang diberikan guru kepada siswa dikategorikan baik.Namun ada beberapa siswa belum mencapai KBM dikarenakan tidak memahami materi yang disampaikan guru.Strategi komunikasi dengan guru dilakukan siswa dengan siswa datang kesekolah untuk memberikan tugas dengan menggunakan bahasa yang sopan. Proses evaluasi yang siswa laksanakan dengan menggunakan aplikasi whatsaap dan ke mengantarkan tugas ke sekolah 1 kali seminggu sesuai dengan perintah ibu guru.

Berdasarkan wawancara peneliti dengan 5 orang guru (guru wali kelas dan mata pelajaran) dan 5 orang siswa kelas IV SD Negeri 066652. Dapat disimpulkan, para guru menyatakan bahwa proses pembelajaran daring sudah dikategorikan baik dengan menggunakan aplikasi whatsapp dan zoom pada masa pandemi covid-19 saat ini. Pemberian materi berupa gambar, video ataupun voice note dan pengisian daftar hadir dilakukan dengan menggunakan aplikasi whatsapp sebagai penunjang kegiatan belajar mengajar.menggunakan aplikasi. Selanjutnya siswa diminta untuk mempelajari materi yang mengunggah materi yang telah diberikan oleh guru lalu siswa dapat melakukan diskusi dengan guru melalui whatsapp. Jika masih ada materi yang kurang jelas siswa dapat bertanya melalui aplikasi 


\section{Jurnal Pendidikan Sains dan Komputer}

whatsapp. Penilaian yang dilakukan guru terhadap siswa yaitu dengan mengumpulkan tugas-tugas siswa dengan pertanyaan yang diberikan siswa guru dapat melihat keaktifan melalui whatsapp dan jika yang tidak punya handphone langsung bertanya.Menurut Juliya.M.dkk (2021) tentang analisis problematika pembelajaran daring dan pengaruhnya terhadap motivasi belajar siswa dengan hasil masih terbatasnya penguasaan teknologi, kesulitan mengakses jaringan internet,ketiadaan fasilitas penunjang belajar, dan kondisi lingkungan yang kurang kondusif.

Berdasarkan wawancara peneliti dengan siswa di SD negeri 066652 Medan Helvetia dapat disimpulkan bahwa proses pembelajaran daring dilakukan dengan menggunakan whatsapp dan zoom dimana sebagian siswa mengisi daftar hadir menggunakan whatsapp dan sebagian lagi datang ke sekolah sekalian mengantarkan tugasnya seminggu satu kali. Proses pembelajaran daring guru hanya memberikan materi sehingga membuat siswa banyak yang kurang paham dengan materi nya. Ada juga siswa yang bertanya kepada orangtuanya ataupun saudara jika tidak mengerti dengan materi tersebut. Dalam proses pembelajaran daring tidak pasti tidak semua dengan berjalan denagn mulus/bagus artinya siswa memiliki hambatan dalam proses pembelajaran daring dengan kurang memahami materi dari guru, tidak memiliki handphone dan sulit untuk bertanya kepada guru. Sejalan dengan penelitian Amalia (2020) tentang analisis kendala peserta didik dalam pembelajaran online dengan temuan kendala mulai dari kouta internet yang kurang memadai, jaringan yang tidak stabil, kurangnya pemahaman siswa terhadap materi yang telah di sampaikan.hal ini di menunjukan bahwa kendala yang paling banyak dirasakan oleh siswa adalah kurang mampu memahami materi yang telah di sampaikan.

Adapun nilai KBM pada SD negeri 066652 Medan dengan rata-rata kelas yang mendapatkan nilai 75 sebanyak 20 siswa.dan 5 orang siswa tidak mencapai ketuntasan dalan KBM. Siswa tidak tuntas pada pelajaran B.inggris, IPA, dan Matematika.Karena mata pelajaran tersebut sulit untuk dipahami siswa, maka dari itu siswa tidak tuntasdiberikan materi pembelajaran tambahan ataupun remedial melalui aplikasi whatsapp. Nilai rata-rata 75 ini terdiri dari mata pelajaran Agama, Pkn, Bahasa inggris, Matematika, IPA, IPS, PJOK, Seni budaya, Bahasa Indonesia.

\section{PEMBAHASAN}

Hasil penelitian menenujukan bahwa proses pembelajaran daring di SD Negeri 066652 Medan dilaksanakan sesuai dengan jam pelajaran yang sebelumnya sudah ditentukan. Dengan pemberian tugas melalui aplikasi whatsapp dan siswa yang tidak mempunyai handphone datang ke sekolah langsung untuk mengantarkannya dan meminta tugas kepada guru.Penilaian di Sekolah SD Negeri 066652 dikategorikan baik dengan perolehan nilai KBM 75. Maka jika ada siswa yang belum tuntas, guru akan memperbaiki nilai yang kurang tersebut dengan memberikan tugas tambahan ataupun remedial sehingga mencapai nilai KBM yang telah ditentukan oleh sekolah.Sejalan dengan penelitian Purnamasari.D.\& Nugraheni.N (2020) menunjukkan masih ada siswa yang mendapatkan nilai tidak memuaskan dan masih banyak siswa yang tidak mengerjakan soal evaluasi.Permasalahan yang dihadapi siswa yaitu jaringan internet yang tidak lancar, tidak memiliki kuota internet, kesulitan memahami pelajaran dan tidak ada sarana Hp atau komputer. Hal ini dengan adanya peran orang tua maka siswa akan terbantu dalam memahami pelajaran, kemudian juga orang tua dapat memantau perkembangan belajar siswa dan mengawasi anaknya agar dapat mengikuti pelajaran daring dengan baik.

Adapun kendala yang terjadi pada saat proses pembelajaran daring masih dapat teratasi oleh guru. Guru dan orangtua siswa ataupun wali saling bekerja sama dalam proses pembelajaran. Siswa yang 
tidak memiliki handphone bisa datang ke sekolah dan memberikan tugasnya kepada guru dan pada kesempatan tersebut siswa dapat bertanya kepada guru, bagian apa saja yang tidak dipahami ataupun sulit dipahami bisa bertanya kepada guru langsung ketika siswa datang kesekolah. Guru dan orangtua siswa saling bekerja sama untuk memberikan informasi mengenai perkembangan anak mereka selama proses pembelajaran daring dirumah dan guru tetap memotivasi siswa untuk tetap semangat dalam mengikuti pembelajaran daring dirumah.

\section{KESIMPULAN}

Berdasarkan hasil penelitian yang telah dilakukan dengan metode kualitatif deskriftif melalui teknik pengumpulan data berupa wawancara, observasi dan dokumentasi yang telah dilakukan di SD Negeri 066652 Medan Proses pembelajara daring di SD Negeri dikategorikan baik dengan menggunakan aplikasi whatsappp dan dan terkadang melalui zoom, dengan didukung berbagai fitur-fitur aplikasi whatsapp group. Guru memberikan materi pembelajaran melalui whatsapp dan mengisi daftar hadir siswa melalui aplikasi whatsapp dan sebagian siswa datang ke sekolah sekali seminggu.

Adapun kendala siswa dalam proses pembelajaran daring yaitu siswa kurang memahami materi yang diberikan, Siswa tidak memiliki handphone harus menunggu orang tua pulang dari pekerjaanya, siswa sulit bertanya antara teman satu dengan yang lain. Namun semua kendala ini dapat diatasi karena ada kerja sama antara guru dan orang tua dalam proses pembelajaran daring dimasa pandemi covid-19.

\section{REFERENSI}

Albab, S. (2020). Analisis Kendala Pembelajaran E-Learning Pada Era Disrupsi di SMK Terpadu AlIslahiya Singosari Malang.Vol 2 .Jurnal Manajemen Pendidikan. e-ISSN: 2657-2230. 46-57.

Akbar. Almas. (2011). Peran Orangtua Dalam Pendampinagn Anak. (Online). http://almasakbar45.blogspot.com/2011//05/peran-orang-tua-dalam-pendampingan-anak.html. Diakses 23 Juli 2021

Amelia, R. dkk. (2020). Analisis Kendala Peserta didik dalam Pembelajaran Online Materi Biologi Di SMP Negeri 3 Bantul.Vol 5, No. 2.ISSN: 2541-2280. 53.

Anggianto, Setiawan. (2018). Metodologi Penelitian Kualitatif. Sukabumi: Jejak. 68

Anugrahana, A. (2020). Hambatan, Solusi, dan Harapan: Pembelajran Daring Selama Masa Pandemi Covid-19 Oleh Guru Sekolah Dasar. Vol.10 (3).Jurnal Pendidikan dan Kebudayaan.282-298.

Anwar, K dkk. (2020). Analisis Pembelajaran Daring Pada Masa Pandemi Covid-19 Di SD Duri Kepa 05. Jakarta: Kebon jeruk.35

Apriliana, dkk. (2020). Problematika Pembelajaran Daring Pada Siswa Kelas IV MI Bastanul Mubtadin Kecamatan Suruh Kabupaten Semarang tahun Pelajaran 2019/2020. Semarang.1-25.

Ardiandra, dkk. (2021). Pembalajaran Dalam Jaringan (Daring) Berbasis Whatsapp Di SD Yapita.Vol. 2(1).ZAHRA: Research and thought Elmentery School of Islam Journal. ISSN: 2723-4932.13-23.

Arikunto. (2009). Evaluasi Program Pendidikan. Jakarta: Bumi Aksara

Azhar \&Arsyad. (2011). Media Pembelajaran. Jakarta: penerbit rajawali pers.23-35. 


\section{Jurnal Pendidikan Sains dan Komputer}

Basar, A.M. (2021). Problematika Pembelajran Jarak Jauh Pada Masa Pandemi Covid-19.Vol. 2 (1).Edunesia: Jurnal ilmiah Pendidikan. e-ISSN: 2722-7790.108-218.

Barnawi, Arifin. (2014). Manajemen Sarana dan Prasarana Sekolah. Jogjakarta: Ar-Ruzz-Media

Bilfaqih.Y, Qomarudin.M.N. (2015). Esensi Penyusunan Materi Daring Untuk Pendidikan Dan Pelatihan.Yogyakarta: DeePublish. 274.

Denzin and Lincoln. (1994). Hand Book of Qualitative Research.Sage Publication.Thousan oaks, London.236-237.

Fatimah, D (2021). Analisis Pelaksanaan Pembelajaran Pada Masa Pandemi Covid-19 disekolah dasar.Skripsi. Universitas Jambi. 1-82

Firdaus. (2020)Implementasi Dan Harapan Pada Pembelajaran Daring Di Masa Pandemi Covid-19.Vol. VI, No. 2.Jurnal Utile.220-225.

Hardani, O. (2020). Pembelajaran Daring Sebagai Upaya Study From home (SFH) Selama Pandemi Covid-19.Vol. 8 (3). Jurnal Pendidikan Administrasi Perkantoran. 498.

Haryanto. (2020). Evaluasi Pembelajaran. Konsep dan Manejemen. ISBN: 978-602-498-148-8.

Indri, Rahmawati. (2020). Analisis Pembelajaran Daring Terhadap Evaluasi Belajar Siswa Kelas IV MI MA.Skripsi.Institut Agama Islam Negeri Salatiga.

Juliya, dkk. (2021). Analisis Problematika Pembelajaran Daring Dan Pengaruhnya Terhadap Motivasi Belajar Siswa. Vol. XII, No. 1. Genta Mulia. ISSN: 2301-6671. 281-294

Kurtanto, E. (2017). Keefektifan Model Pembelajaran Daring Dalam Perkuliahan Bahasa Indonesia di Perguruan Tinggi. Journal Indonesian Languange Education and literature.

Pane, dkk. (2017). Belajar dan Pembelajaran.Vol.3 (2). Jurnal Kajian Ilmu-ilmu Keislaman.e-ISSN: 2460-2345. 338

Purnamasari, D. (2020). Analisis Permasalahan Siswa Pada Proses pembelajaran Daring Kelas 2, 3, dan 4 di SDN Mangkang Kulon 01.Prosiding Webinar Nasional IAHN-TP Palangka Raya.ISBN: 978623-90547-6-2,31-43.

Pustikayasa, M. (2019). Group Whatsapp Sebagai Media Pembelajaran.Vol.10 (2).Journal Ilmiah Pendidikan Agama dan kebudayaan Hindu.P.-ISSN: 2302- 9102, E-ISSN: 2685-7198,53-62

Prawamti, L, dkk. (2020). Kendala Pembelajaran Daring Selama Pandemic Covid-19.Prosiding Seminar Nasional Pascasarjana UNNES.286-291.

Sagala, S. (2010).Supervisi Pembelajaran Dalam Profesi Pendidikan. Bandung: Alfabeta.61

Sari, R.P, dkk. (2021). Dampak Pembelajaran Daring Bagi Siswa Sekolah Dasar Selama Covid-19.Vol.2 (1).Jurnal ilmiah Kependidikan. ISSN 2721-8112.10-15

Siahaan, S. (2020). Efektifitas Penerapan Strategi Contextual Teaching and Learning (CTL) Dalam Meningkatkan Hasil Belajar Siswa Pada Mata Pelajaran PKn Sekolah Dasar. Medan 
Jurnal Pendidikan Sains dan Komputer

Volume 2, Number 1, February 2022 e-ISSN: 2809-476X

https://doi.org/10.47709/jpsk.v2i1.1371

Sidiq, U. dkk. (2019). Metode penelitian Kualitatif Di Bidang Pendidikan. CV Nata Karya. ISBN: 978$602-5774-41-6$

Sugiyono. (2013). Metode Penelitian Kuantitatif dan kualitatif dan $R \&$ D.Bandung: Alfabeta.78

Zunaika, G. (2020). Implementasi Pembelajaran Daring Di Madrasah Ibtidaiyah study pada Guru MI Istiqomah Ma'arif NU Mojokerto Kabupaten Sragen Tahun Pelajaran 2019/2020.Skripsi.Institut Agama Islam Negeri Salatiga.1-110. 